\title{
The Sex Ratio: A Scientific Glimpse of the Holy Qur'ān
}

\author{
S.M. Bakir, M.B.CH.B., M.Sc., Ph.D., Hossam E. Fadel, M.D. \\ Riyadh, Saudi Arabia and Augusta, Georgia, U.S.A.
}

DOI: http://dx.doi.org/10.5915/23-1-15223

\begin{abstract}
A verse from the Holy Qur'ān implies that there are more male than female births. This is in agreement with the well known fact that the sex ratio is in favor of males from birth and at least up to four years of age.
\end{abstract}

Key words: Qur'ān, sex ratio

The Holy Qur'ān addresses all mankind. It talks about the past, the present, and the future. The true and complete interpretation of all its verses will not be known until the Day of Judgement. The Qur'ānic miracles are unlimited so that the illiterate as well as the intelectuals find this book fascinating. However, believers are encouraged to think, study, and try to derive these interpretations. Although the Qur'ān is not meant to be a book of science, it is clear that it contains scientific facts which were revealed 14 centuries ago, and which only now can we explain. Much has already been written about the references from the Holy Qur'ān to embryologic development. ${ }^{1,2}$ we will draw attention to another scientific glimpse from the Holy Qur'än. It deals with the number of male/female births (the sex ratio). ${ }^{3}$

\section{Allāh says:}

"O mankind! reverence your Guardian-Lord who

From the Department of Physiology College of Medicine, King Saud University Riyadh, Saudi Arabia, and Department of Obstetrics and Gynecology, University Hospital

Augusta, GA, U.S.A.

Reprint Requests: S.M. Bakir, M.B.Ch.B. Department of Physiology

College of Medicine, King Saud University

Riyadh, P.O. Box 2925, Saudi Arabia. created you from a single person, created, of like nature his mate, and from them twain scattered (like seeds) countless men and women ..."”

The verse mentions "countless men and women". Notice that men came before women, and if the inference is right, it means that there are more male than female births.

It is a fact that the sex ratio at birth is in favor of males. In many different populations, the ratio of male to female births has ben found to be $106: 100$. $^{4}$

The New Caxton Encyclopedia ${ }^{5}$ reports that an estimation of the population in thousands by age and sex in the United Kingdom, carried out in June, 1976, showed that in the age group from birth to four years, the number in thousands of males was 1923.7 versus 1813.9 for females. The reason for this excess of males is not known, but various explanations have been put forward.

In males, there are 22 pairs of autosomes plus a large $\mathrm{X}$ chromosome and a small $\mathrm{Y}$ chromosome. In females there are 22 pairs of autosomes plus two $X$ chromosomes. Because the $\mathrm{Y}$ chromosome is smaller and lighter than the $\mathrm{X}$ chromosome, it has been hypothesized that sperms containing the $\mathrm{Y}$ chromosome are lighter and are able to swim faster up the female genital tract, thus reaching the ovum more rapidly, thus accounting for a higher percentage of male versus female conceptuses. ${ }^{6}$

Another mechanism has been proposed. The fact 
that the male conceptus is more antigenically different from the mother may lead to its preferential implantation and growth.?

In conclusion, if this interpretation of this Qur'ānic verse ${ }^{3}$ is correct, then a fact which was revealed in the Holy Qur'an 14 centuries ago has now been explained.

\section{References}

1. Moore KL, Azzindani AMA: The Developing Human, Clinically Oriented Embryology, with Islamic Additions. Third Edition, Philadelphia: W.B. Saunders Co, 1982.

2. Moore KL: A scientist's interpretation of references to embryology in the Qur'an. JIMA 1986;18:15-17.

3. Glorious Qur'ān, Chapter 4, Verse 1.
4. Edwards RG: Early Human Development from the Oocyte to Implantation. In: Scientific Foundations of Obstetrics and Gynecology. Chapter 15. EE Philipp, J Barnes, M Newton (eds). Chicago: Yearbook Medical Publishers, 1977, p 235.

5. The New Caxton Encyclopedia, Vol 1, p 36, Caxton and English Education Programmes International, LTD, and Instituto Georgiafico de Agostini, Italy, 1986.

6. Ganong WF: Review of Medical Physiology, p 343. Los Altos, California: Lange Medical Publications, 1985.

7. Beer AE, Billingham RE, Scott IR: Immunogenetic aspects of implantation, placentation, and feto-placental growth rates. Biol Reprod 1975:12;176. 